\title{
COVID-19 and International Organizations: Challenges and Opportunities from the Perspective of Good Governance and the Rule of Law
}

\section{Introduction to the Forum}

\author{
Julinda Beqiraj \\ Bingham Centre for the Rule of Law, British Institute of International and \\ Comparative Law (BIICL), London, United Kingdom \\ j,beqiraj@biicl.org
}

\section{Francesca Ippolito}

Associate Professor of International Law, University of Cagliari, Sardinia, Italy; Affiliate Professor to the DIRPOLIS, Scuola Superiore Sant'Anna, Pisa, Italy francescaippolito@unica.it

\section{International Organizations and the COVID-19 Pandemic}

Almost two years since the COVID-19 outbreak, the extreme pressure put by the pandemic on legal systems worldwide cannot be ignored. Governments have struggled to adapt existing legislative frameworks, administrative functions, and executive decision-making to the fast-changing and complex situation of the pandemic emergency. In the case of International Organizations (IOs), the crisis, involving disruptions of daily activities, as well as of core civil, political, economic and social rights, has put to test their everyday operations, often questioning their ability to realize their mandate.

Although the pandemic is far from left behind and the lessons learnt may not be fully captured yet this special Forum comes at a critical moment in time and serves as an "along the way' assessment of the challenges encountered, and the solutions implemented. As governments and IOs (slowly) resume their activities and prepare to go back to normal operation modes, an assessment of what has been done so far and of the responses to the challenges posed by the pandemic, is a precious exercise for the purpose of identifying areas, activities and approaches allowing IOs to play a better role in cases of public (health) emergencies comparable to COVID-19. The Forum discusses 
these issues through the lens of compliance with good governance and rule of law principles and standards.

Good governance and the rule of law are critical enablers of trust. By reducing arbitrary exercise of power, they create the legitimacy frame around governments' and IO's actions and ensure that they adhere to their obligations under national and international law, act in transparent, accountable, non-arbitrary ways, consider issues such as inequality and poverty and are restricted from disproportionate interference with rights and liberties. These all are boosters of trust.

Responses to public emergencies (including health emergencies) are often introduced and/or implemented through laws and regulations. Adherence to rule of law safeguards and good governance principles when adopting and enacting such responses are expected to strengthen public trust in institutions and consolidate the legitimacy of the actions undertaken and the measures adopted. This should ultimately bolster their effectiveness through increased compliance.

In normal times, or when dealing with localised crises, the role of International Organizations and the importance of multilateralism in building public trust and seeking to create a level playing field for governments and other international actors is well understood and acknowledged. Even more so, when responding to, and recovering from, public health emergencies of the scale of COVID-19, IOs have a crucial role to play in building and maintaining public trust, and they can do so by abiding to good governance and rule of law principles. In addition to building trust and confidence, compliance with good governance and rule of law standards in the international responses to global health crises is also expected to result in a better, internationally coordinated, response to future crises.

In addition to the introduction, which provides the conceptual frame on good governance and the rule of law and why these are important and desirable for IOs, the Forum brings together seven contributions - on the World Health Organisation (WHO), the World Trade Organization (WTO), the International Labour organization (ILO), the United Nations (UN) Organization, the World Bank (WB), the European Union (EU), and international human rights bodies - which critically discuss the responses and action taken to contain the impact of the COVID-19 pandemic and respond to the challenges posed by it.

Good Governance and the Rule of Law: Domestic and International Applications

The rule of law and good governance are running themes of the Forum and provide the linking thread among the different contributions. Whilst both 
concepts are broad ones with multiple interpretations and applications, a number of authoritative understandings have emerged over time, which inform this Forum. An introduction to the understanding of the concepts of rule of law and good governance is thus necessary before moving to a brief presentation of the Forum contributions.

\subsection{Good governance}

Good governance is associated with efficient and effective administration. It provides a set of values that should guide the work of governments, together with performance standards for accountability. ${ }^{1}$ These should inform the development of policies, programmes and legislative frameworks, including during emergencies.

The content and core elements of the concept of good governance, have been developed in the working definitions adopted, for instance, by the World Bank $(\mathrm{WB})^{2}$ the United Nations $(\mathrm{UN})^{3}$ and the Council of Europe. ${ }^{4}$ All these definitions cover aspects such as, efficiency and effectiveness, transparency and access to information, sound financial management, accountability, and compliance with the rule of law.

\section{$2.2 \quad$ The rule of law}

The rule of law doctrine has been developed for and is usually applied to domestic legal orders. The concept of the rule of law has different historical roots and traditional perspectives. ${ }^{5}$ The modern concept of the rule of law was developed in particular by the British constitutional lawyer Dicey in his Introduction to the Study of the Law of the Constitution. ${ }^{6}$ Thus, in the common

1 Meetika Srivastava, 'Good Governance - Concept, Meaning and Features: A Detailed Study' (2009) SSRN Scholarly Paper ID 1528449.

2 United Nations Economic and Social Commission for Asia and the Pacific, What is Good Governance?, July 2009 <www.unescap.org/resources/what-good-governance>.

3 The World Bank, Governance and development, $1992<$ documents1.worldbank.org/curated/ en/604951468739447676/pdf/multi-page.pdf>.

4 The Council of Europe refers to 12 principles of good governance, which have been endorsed by a decision of the Committee of Ministers of the Council of Europe in 2008, <www.coe.int/ en/web/good-governance/12-principles>.

5 For a summary and analysis see Simon Chesterman, 'An International Rule of Law' (2008) 56 American Journal of Comparative Law 331; Jeffrey Jowell, 'The Rule of Law and its Underlying Values' in J. Jowell and D. Oliver (eds), The Changing Constitution, (Oxford University Press, 6th edition, 2007) 6-7 and references; Kaarlo Tuori, 'The Rule of Law and the Rechtsstaat' in K. Tuori, Ratio and Voluntas: The Tension Between Reason and Will in Law, (Routledge, 1st edition, 2010) 8.

6 Albert Venn Dicey, Introduction to the Study of the Law of the Constitution, (Liberty Classics, 1885). 
law tradition, the rule of law is a political ideal, which contains at its core a number of basic principles, aimed at limiting the powers of the government. ${ }^{7}$

Beyond the different modulations of the definition of the rule of law adopted by different authors in literature, a distinction is generally made between 'thin' and 'thick' conceptions. ${ }^{8}$ 'Thin' versions of the rule of law concern how any given law is made and applied. The 'thin' conception includes the requirement that States make clear laws, that they do so in a transparent manner, that the law is equally applied, and that States enable fair and impartial dispute resolution and access to justice. Instead, the 'thick' conception of the rule of law moves beyond procedural safeguards to also consider the content of the law. In this view, the rule of law requires state compliance with international law, and adequate protection of fundamental human rights.

In 2010, Lord Bingham had grasped the essence of the principle to be that:

"all persons and authorities within the state, whether public or private, should be bound by and entitled to the benefit of the laws publicly made, taking effect (generally) in the future and publicly administrated in the courts". 9

In his book 'The rule of law', Lord Bingham offers a clear and concise functional definition of the rule of law consisting of eight components: (i) accessible, intelligible, clear and predictable laws, (ii) legal questions should be determined according to law, not by the exercise of discretion, (iii) the law should apply equally to all, except where objective differences justify differentiation, (iv) exercise of power by public officials reasonably, in good faith, for the purpose for which they were conferred and without exceeding their limits, (v) adequate protection of fundamental human rights in the law, (vi) access to dispute resolution (without prohibitive cost or inordinate delay), (vii) fair adjudicative procedures, and (viii) compliance with international law obligations. ${ }^{10}$ These eight ingredients have been further distilled into four essential

7 Jeremy Waldron, 'The Concept and the Rule of Law' (2008) 43(3) Georgia Law Review; Lon L. Fuller, The Morality of Law (Yale University Press, revised edition,1969); Joseph Raz, The Rule of Law and its Virtue (Oxford University Press, 1979); John Finnis, Natural law and natural rights (Oxford University Press, 1980).

8 Jorgen Moller and Svend-Erik Skaaning, 'Systematizing Thin and Thick Conceptions of the Rule of Law' (2012) 33 Justice Systems Journal 136; Nicolas Barber, 'Must Legalistic Conceptions of the Rule of Law Have a Social Dimension? (2004) 17 Ratio Juris 474; Paul Craig, 'Formal and Substantive Conceptions of the Rule of Law: An Analytical Framework' (1997) Public law 467.

$9 \quad$ Lord Tom Bingham, The Rule of Law (Penguin, 2010) 8.

10 Ibid. 
components of the rule of law: legality, legal certainty, equality and access to justice and rights. ${ }^{11}$

\subsection{Relevance of the concepts of good governance and the rule of law for IO's}

The concepts of good governance and rule of law have been historically developed and implemented within domestic legal systems. More recently, however, the importance of complying with the rule of law at the international level has been increasingly recognized. ${ }^{12}$

Considering the relations among states under international law and between these and international organizations, issues of compliance with good governance and rule of law standards may arise in at least three cases: (i) in the international relations between states, including as members of IOs; (ii) when international organizations perform their activities in the field, and; (iii) in the internal operations, management and functioning of IOs. The three perspectives are closely related. On the one hand all activities of International Organizations ultimately depend on the consent of states and are IOs accountable to them. On the other, with the consent of the member states, the institutional and competence-related features of certain IOs allow them to enjoy a higher degree of autonomy and independence, including with regard to setting standards and strengthening the rule of law in their governance.

While there are notable differences as regards the institutional structure and power relations within states and within IOs, it is both possible and desirable to translate and apply good governance and rule of law standards internationally. As a first step, the rule of law has been recognised as a foundational legal value and a principle of constitutional relevance, not only in national constitutions but also in international documents. The preamble to the United Nations' Declaration on Human Rights states that, "Whereas it is essential,

11 Jeffrey Jowell and Colm O'Cinneide, The Changing Constitution (Oxford University Press, 9th edition, 2019) 16; Robert McCorquodale, The Rule of Law in International and Comparative Context (British Institute of International and Comparative Law, 2010).

12 See Robert McCorquodale, 'Defining the International Rule of Law: Defying Gravity?' 65(2) (2016) International and Comparative Law Quarterly 277-304; Eric Selous, 'The Rule of Law and the Debate on it in the United Nations', in C. Feinäugle (ed), The Rule of Law and Its Application to the United Nations (Max Planck Institute Luxembourg for International Law, 2016); Richard Collins, 'The Rule of Law and the Quest for Constitutional Substitutes' 83 (2014) Nordic Journal of International Law 87; Hans Correll, 'A Challenge to the United Nations and the World: Developing the Rule of Law' 18 (2004) Temple International and Comparative Law Journal, 399; Rosalyn Higgins, 'The Rule of Law: Some Sceptical Thoughts' in R. Higgins (ed), Themes and Theories: Selected Essays, Speeches and Writings in International Law (Oxford University Press, 2009). 
if man is not to be compelled to have recourse, as a last resort, to rebellion against tyranny and oppression, that human rights should be protected by the rule of law".13 In the Statute of the Council of Europe, the rule of law is referred to as one of the three "principles which form the basis of democracy", alongside individual freedom and political liberty. ${ }^{14}$ In the Treaty on the European Union it is listed among the founding values of the Union, alongside equality, freedom, democracy, respect for human rights, etc. ${ }^{15}$ While such sources only contain references to the concept, working definitions of the rule of law have been developed by the main institutions of the respective organizations.

For the UN Secretary General:

"The 'rule of law' is a concept at the very heart of the Organization's mission. It refers to a principle of governance in which all persons, institutions and entities, public and private, including the State itself, are accountable to laws that are publicly promulgated, equally enforced and independently adjudicated, and which are consistent with international human rights norms and standards. It requires, as well, measures to ensure adherence to the principles of supremacy of law, equality before the law, accountability to the law, fairness in the application of the law, separation of powers, participation in decision-making, legal certainty, avoidance of arbitrariness and procedural and legal transparency."16

For the Council of Europe's Commission for Democracy Through Law (the Venice Commission), despite differences of opinion, consensus exists on the core elements of the Rule of Law which include both formal and substantive elements "(1) Legality, including a transparent, accountable and democratic process for enacting law; (2) Legal certainty; (3) Prohibition of arbitrariness; (4) Access to justice before independent and impartial courts, including judicial review of administrative acts; (5) Respect for human rights; and (6) Non-discrimination and equality before the law."17

13 UN General Assembly, Universal Declaration of Human Rights, (217 A (III)), 10 December 1948.

14 Statute of the Council of Europe, ETS 1, Preamble.

15 European Union, Consolidated version of the Treaty on European Union, (2008/C 115/o1) 13 December 2007.

16 UN Secretary General, The rule of law and transitional justice in conflict and post-conflict societies, (S/2004/616o) 23 August 2004, para 6 <www.securitycouncilreport.org/atf/

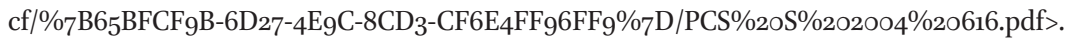

17 Council of Europe, Venice Commission, The rule of law checklist, 2016, $10<$ www.venice.coe. int/images/SITE\%2oIMAGES/Publications/Rule_of_Law_Check_List.pdf $>$. The definition developed by the Venice Commission specifically acknowledges the work of Lord Bingham, 
For the EU Commission "the rule of law is the source of applicable principles in the legal order of the Union that can be fully enforced before a court". 18 These include legality, legal certainty, prohibition of arbitrariness, independent and effective judicial review, including with regards to human rights, and equality before the law.

Summarising, in the words of the Venice Commission, "The Rule of Law is a concept of universal validity" which both guides and constrains the exercise of public power. Despite differences on the precise definition, it can be safely claimed that there is consensus among scholars and governments on some of the core elements of the rule of law, such as legality, legal certainty, equality and access to justice and rights, which are recurring elements in all definitions. Can these be transferred to IOs to guide and provide a frame for their actions and activities?

Expanding the concept of national rule of law to IOs is not a simple exercise. ${ }^{19}$ However, it is possible to do so by avoiding the well-worn definitional debates on what the rule of law is, and focussing instead on the question of what the rule of law (and good governance) aims to protect and how can this be achieved. ${ }^{20}$ Accordingly, the core elements of good governance and the rule of law, such as efficiency and effectiveness, transparency, accountability, legality, legal certainty, equality and access to justice and rights, would equally apply to IOs at the international, level, and contribute to the credibility and legitimacy of IOs. This is even more the case when responding to, and recovering from, public health emergencies of the scale of COVID-19.

Applying these principles to International Organizations is also desirable. First, it would be incoherent for IOs (e.g., the UN, WB, EU) to promote and request compliance with good governance and rule of law standards in the countries where they operate, while exempting their institutional dimension,

and adopt a similar broad approach, proscribing arbitrary behaviour by governments and protecting human rights, in addition to the formal aspects of the rule of law.

18 EU Commission, Annex I: The Rule of Law as a foundational principle of the Union (COM(2014) 158 final), 11 March 2014, note 2.

19 See Robert McCorquodale, 'Defining the International Rule of Law: Defying Gravity?' 65(2) (2016) International and Comparative Law Quarterly 277-304; Simon Chesterman, 'An International Rule of Law' 56 (2008) American Journal of Comparative Law 331; Simon Chesterman, "I'll Take Manhattan": The International Rule of Law and the UN Security Council' 1 (2009) Hague Journal on the Rule of Law 67.

20 José E. Alvarez, 'International Organizations and the Rule of Law', International Law and Justice Working Papers, IILJ Working Paper 2016/4 Global Administrative Law Series, NYU School of Law, 15; Simon Chesterman, 'An International Rule of Law' 56 (2008) American Journal of Comparative Law 342 . 
behaviour and operations from such scrutiny. ${ }^{21}$ At the same time there are, indeed, increasing examples of the recognition that adherence to good governance and rule of law principles - or to most of them most of the time - matters for the purpose of trust, legitimacy and accountability, which are triggered when arbitrary exercises of power is prevented.

At the United Nations level, the "need for universal adherence to and implementation of the Rule of Law at both the national and international levels" was endorsed by all Members States of the United Nations in the 2005 Outcome Document of the World Summit. ${ }^{22}$ Also, following the operational definition developed by the Secretary General ${ }^{23}$ and publication of "Rule of Law Indicators" in 2011, ${ }^{24}$ the United Nations General Assembly adopted in 2012 a Declaration of the High-level Meeting of the General Assembly on the rule of law at the national and international levels, which recognises that:

"[...] the rule of law applies to all States equally, and to international organizations, including the United Nations and its principal organs, and that respect for and promotion of the rule of law and justice should guide all of their activities and accord predictability and legitimacy to their actions." 25

Also:

"[...] good governance at the international level is fundamental for strengthening the rule of law, and stress the importance of continuing efforts to revitalize the General Assembly, to reform the Security Council

21 Jeremy Waldron refers to this as 'farmyard justice'. See Jeremy Waldron, 'The UN Charter and the Rule of Law', Keynote Address, Nov. 1, 2015, available as a video <www.youtube.com/ watch?v=N6Lv3LorWJM>.

22 UN General Assembly, Resolution adopted by the General Assembly on 16 September 2005, World Summit Outcome, (A/RES/60/1) 24 October 2005, para $134<$ www.un.org/en/ development/desa/population/migration/generalassembly/docs/globalcompact/A_ RES_6o_1.pdf >.

23 Supra text accompanying note 16.

24 UN, Rule of Law Indicators. Implementation Guide and Project Tools, joint publication of the United Nations Department of Peacekeeping Operations (DPKO) and the Office of the United Nations High Commissioner for Human Rights (OHCHR) <www.un.org/en/events/ peacekeepersday/2011/publications/un_rule_of_law_indicators.pdf $>$.

25 UN General Assembly, Resolution adopted by the General Assembly, Declaration of the Highlevel Meeting of the General Assembly on the Rule of Law at the National and International Levels, 30 November 2012, para 2, <https://www.un.org/ruleoflaw/files/A-RES-67-1.pdf>. 
and to strengthen the Economic and Social Council, in accordance with relevant resolutions and decisions." 26

More recently, the Sustainable Development Agenda with its 17 Sustainable Development Goals (SDG s) and 169 targets to be delivered by 2030, unanimously adopted by the UN General Assembly in September $2015,{ }^{27}$ recognises that "democracy, good governance and the rule of law, as well as an enabling environment at the national and international levels, are essential for sustainable development" ${ }^{28}$ In particular Goal 16 commits States to "Promote peaceful and inclusive societies for sustainable development, provide access to justice for all and build effective, accountable and inclusive institutions at all levels". The achievement of the SDG s, including Goal 16, will be assessed against a number of targets, some of which incorporate rule of law components. Notably, Target 16.3 sets out to "Promote the rule of law at the national and international levels and ensure equal access to justice for all"; Targets 16.6 and 16.7 aim to "Develop effective, accountable and transparent institutions at all levels" and "Ensure responsive, inclusive, participatory and representative decision making at all levels", and Target 16.8 aspires to "Broaden and strengthen the participation of developing countries in the institutions of global governance".

As regards the EU, in its 2014 New Framework to Strengthen the Rule of Law, the European Commission recalls that "the principle of the Rule of Law has progressively become a dominant organisational model of modern constitutional law and international organisations (including the United Nations and the Council of Europe) to regulate the exercise of public powers". ${ }^{29}$

Another important recognition was made in a 2020 Communique of the G2o Trade and Investment Ministerial Meeting, where the G2o members reiterated the objective "to realize a free, fair, non-discriminatory, transparent, predictable and stable trade and investment environment, and to keep our markets open." ${ }^{30}$ The World Trade Organization (WTO) plays a crucial role in this regard, specifically in supporting economic recovery from the COVID-19

26 Ibid para 35 .

27 UN General Assembly, Resolution adopted by the General Assembly, 'Transforming our world: the 2030 Agenda for Sustainable Development' (A/RES/70/1) 25 September 2015, <www. un.org/ga/search/view_doc.asp?symbol=A/RES/70/1\&Lang=E $>$.

28 Ibid para 9 .

29 Communication from the Commission to the European Parliament and the Council, A new EU Framework to strengthen the Rule of Law, COM(2014) 158 final, Brussels, 11 March 2014, 3-4.

30 G2o Trade and Investment Ministerial Meeting Communique, 22 September 2020, $11<w w w$. g2o.utoronto.ca/2020/G2OSS_Communique_TIMM_EN.pdf>. 
pandemic. During the meeting, G2o members put together a list of principles that underpin the WTO, comprising the foundational principles embodied in the Marrakesh Agreement and included in the covered agreements, with some of these foundational principles are also being reflected in the Marrakesh Declaration. Notably, the rule of law figures on top of a list of eight foundational principles, followed by transparency, non-discrimination and inclusiveness.

These are a few but meaningful examples of the recognition of the importance of good governance and rule of law principles for both national systems and International Organizations. The recurring theme of the Forum is that these principles are even more precious during times of emergency - COVID-19 provides a topical example of a global emergency - when states revert to protectionist attitudes and cooperation and coordination is needed more than ever. Against this conceptual framework (i.e., through the good governance and the rule of law lenses), the Forum assesses the role of IOs in contributing to building public trust and enabling internationally coordinated responses during the COVID-19 pandemic, with a view to drawing lessons about desirable adjustments in the way forward.

\section{3 Presentation of the Contributions}

The Forum brings together seven contributions, covering the International Organizations that had a major role and/or were mainly affected (by reason of their mandate) by the COVID-19 pandemic. Each contribution addresses one or more international organizations and/or bodies, and analyses their respective responses during the pandemic, the challenges faced, and the solutions identified to deal with the disruptions. Authors also comment on the opportunities that have arisen (if any) and reflect on the need for adjustments in the way forward, stemming from a rule of law and good governance perspective.

While each contribution contains details of the institutional mechanisms, practices, and challenges at each institution, three recurring themes can be identified across the different articles. The first one is that IOs and their member states should not miss the opportunity to use the COVID-19 pandemic as a catalyst for change, be this through institutional change, procedural amendments, or revisions regarding the substance of protection - echoing Churchill's quote "Never let a good crisis go to waste". Secondly, all contributions acknowledge the importance of interrelatedness, multilateralism, and cooperation at different levels: between states, between IOs, and between public and private actors. Thirdly, and quite importantly, there is a returning urge in the different 
contributions for caution not to lose sight of the social justice and human rights dimension in all policy responses, especially during the recovery stage.

In the paper on the WHO, Gian Luca Burci and Jennifer Hasselgård-Rowe examine the role of the organization in the prevention and control of the international spread of diseases, with particular regard to the COVID-19 case. They do so in the light of four good governance and rule of law elements against which they assess the responses of the WHO - quality of the rules (clarity, responsiveness and fairness); legitimacy of processes to implement the rules; accountability (both for member states and WHO); and respect for human rights. Their analysis reveals areas where the Organization could strengthen compliance with the good governance and rule of law principles. Such challenges are sometimes due to the way normative instruments such as the IHR are designed; in other cases, they are related to the features of the organization itself. The authors acknowledge that the magnitude of the COVID-19 crisis may provide the appropriate trigger for an in-depth review of the challenges that, besides weakening the effectiveness of WHO as an institution and a global health governance actor, also weaken the overall multilateral framework to guarantee global health security. While the COVID-19 pandemic can be transformed into an opportunity for bold reforms, good governance and rule of law standards "should provide a compass" in such reform process.

The idea of using the COVID-19 pandemic as an opportunity for reform is also developed the article on the WTO by Gabrielle Marceau and Shivani Garg. International trade is crucial at all stages of the pandemic, including during the recovery period. Food, medicines, and vaccines are made available through international commerce and trade, and the WTO has played an active role in coordinating policy responses to address the crisis. The article is rich with examples where Members and the organization adjusted their practices to ensure and facilitate multilateral approaches to the crisis and an effective global response. Notably, since the beginning of the crisis, the WTO has played a crucial role in promoting and enhancing transparency (especially through the Trade Policy Review Mechanism). Another key area where the WTO has served as a focal point concerns the debate on the waiver of patent protections on vaccines and the recognition of the need to expand massively vaccine production capacity. The article highlights the essential role of collaborations in facilitating equitable access to vaccines, including innovative forms of collaborations between IOs, public-private partnerships, and competing enterprises, as the COVAX example shows. Increased transparency and access to information, the provision of a forum for policy coordination, and the identification of solutions to ensure equitable access to vaccines, all promote good governance 
and the rule of law, legitimizing the Organization's role as a global governance forum.

The COVID-19 pandemic has put unprecedented strain also on labour markets and decent work across the world. In line with other contributions in this Forum, the article on the ILO by Anne Trebilcock argues that the COVID-19 pandemic has provided both challenges and opportunities for the Organization, from a good governance and rule of law perspective. She refers to a "two-pronged challenge" posed by the pandemic. On the one hand, such challenges involved the everyday functioning of the institutions and bodies of the organization, in terms of reduced representation, transparency and access to information, as a result of virtual meetings, even "causing a shock in deliberation". Nevertheless, the ILO was able to build on its past experience in governance and legal flexibility to pursue its mandate during the pandemic. The crisis permitted the introduction of new practices, also involving digital technology, that raised efficiency. The second prong of the challenge regarded the realization of the mandate of the organization by influencing post-pandemic recovery to be social justice oriented. In this respect, the author contends that ILO's pandemic-related work so far would have benefitted from a stronger gender dimension. She joins one of the recurring themes of this Forum that 'Building back better' and in a sustainable way will require coherent international cooperation. The article concludes with the assertion that the pandemic experience has provided "a trial run for revving up multilateral governance" to confront a bigger existential challenge for humanity, such as climate change.

As an organization with worldwide operations, the UN was both advantaged and disadvantaged in adjusting to the exceptional circumstances of COVID-19. The author, Christiane Ahlborn, argues that in fulfilling its mandate to address emergencies of different kinds and sizes, the UN had developed a significant digital presence and agility in the years prior to the outbreak of COVID-19, which resulted useful during the pandemic. Despite the numerous challenges, the UN was thus able to demonstrate its resilience and maintained high standards of good governance and the rule of law in its own legal order. To demonstrate this point, the author discusses examples from the everyday activities of four UN institutions and bodies, namely the Secretariat, the General Assembly, the Security Council and the International Court of Justice. She also contends that "the crisis also led to introspection in a way that has not happened in quite some time". The crisis coinciding with the 75th anniversary of the UN Charter, presents an opportunity for the organization to improve its actions in terms of transparency, accountability, predictability of the rules, which in turn will strengthen the legitimacy of the UN's activities. 
In the field of international public health law and policy, severely put to test by the COVID-19 emergency, financing pandemic containment responses is a highly debated and controversial issue. The article by Francesco Seatzu asks whether the WB and its Pandemic Emergency Financing Facility (PEF) may be perceived as effective, and addresses this question by referring to their mandates, their inherent capacity for enhancing accepted global legal standards and rules on public health and their funding methods and practices, both historically and during the COVID-19 emergency. The author argues that effectiveness is closely connected to acknowledgement of legitimacy and the respect and promotion of rule of law standards, on which depends acceptance of international institutions, including international financial institutions. The analysis in the article brings to the conclusion that the WB's functional and management structures, but not the PEF's structures and management, have made noteworthy progress in these regards, and notwithstanding some deficiencies and peculiarities, they present multiple elements of legitimate decision-making and lending practices. For this reason, the author claims that "the WB has indeed established itself as the most influential player with respect to international public health emergency policies".

The article by Francesca Ippolito addresses the challenges (and responses thereto) for international judicial and quasi-judicial human rights bodies and the International Criminal Court. It covers the practice of several regional human rights protection bodies and compares it to that of UN human rights treaty bodies and the ICC. The author uses the interesting medical metaphor of 'triage' (i.e., designing a system of priorities to maximize impact, during an emergency), to discuss the measures taken by institutions to preserve the rule of law, both in their internal functioning as well as in promoting the rule of law within national legal orders when monitoring the States' compliance with international human rights obligations and guidelines about COVID-19. She concludes that, overall, procedures in the different bodies were developed to ensure that the rule of law is maintained, which makes it easier to respond to similar crises in the future. However, the pandemic also sheds light on the need to revisit some substantive concepts in human rights law such as making a connection between climate change and health crises, and "rethink the prism of categories of rights in the name of the normative position of interdependence and indivisibility of rights".

Finally, the article by Joelle Grogan covers a regional international organisation, the EU, and argues about the limited role of the Union in the management and governance of the pandemic because of its limited competences in the public health area. The COVID-19 example is put in strong contrast with 
the financial crisis example, where the Union was able to be more actively involved. According to the author, even the limited coordination and support that the EU could offer in the first stages of the pandemic was hindered by "lack of preparation, political will, and capacity". She points out, however, to more recent signs (e.g., the $\mathrm{EU}_{4} \mathrm{Health}$ Regulation) that the pandemic may be a catalyst for further development of EU health policy in the context of reaction and response to pan-European health crises. Yet, she also acknowledges the strong arguments in favour of maintaining public health responses at the level of Member States. The article concludes with a statement on the importance of clear laws, drafted with public input and parliamentary scrutiny, which would encourage and bolster public trust in governance both at national and EU level.

\section{Biographies}

Julinda Beqiraj is the Maurice Wohl Senior Research Fellow in European Law at the Bingham Centre for the Rule of Law (British Institute of International and Comparative Law - BIICL). She is a member of the Horizon 2020 project 'Reconciling Europe with its Citizens through Democracy and Rule of Law' (RECONNECT) where she carries out research on rule of law challenges in Europe and on the compatibility of COVID-19 pandemic responses with human rights, and the rule of law. At the Bingham Centre, she leads a project on the Rule of Law, legitimacy and effective COVID-19 control technologies; and convenes trainings and events on international trade law topics. The editing of this forum and the research undertaken have been supported by RECONNECT funding.

Francesca Ippolito is Associate Professor of International Law at the University of Cagliari and Affiliate Professor to the DIRPOLIS, Scuola Superiore Sant'Anna, Pisa. Her interest in teaching and research ranges from international law, European law, international human rights law, international environmental law and international migration law, with a special focus on comparative approaches of regional and universal human rights mechanisms. Her most recent books include: F. Ippolito, Understanding vulnerability in international human rights law (Editorale Scientifica, Napoli, 2020) 472; F. Ippolito, G. Borzoni, F. Casolari (eds), Bilateral Relations in the Mediterranean. Prospects for migration issues (Edward Elgar, 2020); F. Ippolito, M.E. Bartoloni, M. Condinanzi (eds), The proliferation of integration principles in EU law: towards a more policy consistency? (Routledge, 2018). 